\title{
Lamiyya by al-Shanfara and its Commentaries: Copies Available in the Holdings of the Institute of Oriental Manuscripts and the Oriental Department Collection, Gorky Research Library
}

\author{
Yafia Yousif Jamil Hana, A. A. Mokrushina
}

St. Petersburg State University,

7-9, Universitetskaya nab., St. Petersburg, 199034, Russian Federation

For citation: Hana Yafia Yousif Jamil, Mokrushina A. A. Lamiyya by al-Shanfara and its Commentaries: Copies Available in the Holdings of the Institute of Oriental Manuscripts and the Oriental Department Collection, Gorky Research Library. Vestnik of Saint Petersburg University. Asian and African Studies, 2019, vol. 11, issue 4, pp. 493-512. https://doi.org/10.21638/spbu13.2019.406

The article "Lāmiyya by al-Shanfarā and its commentaries: Copies available in the holdings of the Institute of Oriental Manuscripts and the Oriental Department collection, Gorky Research Library" reviews the problem of studying and describing oriental manuscripts, which gains more relevance in recent times. This research presents life facts of the famous pre-Islamic poet al-Shanfarā and the features of his most famous work, Lāmiyya. The study focus on the copies of this work, as well as copies of its commentaries stored in the holdings of the Institute of Oriental Manuscripts and the Oriental Department collection, Gorky Research Library, SPbSU. The poetry of al-Shanfarā is traditionally compared with classical muallaq, where the authors praise tribal patriotism against the main idea - a life in exile. Lāmiyya got its name for the special repetitive rhyme. Among European researchers, this qașīda is also known as "The Desert Song". The authors analyze the features of various copies of al-Shanfaräs work and discuss the most important aspects of various commentaries on his work. The article provides illustrations of some sheets of al-Shanfarās copies and copies of Lāmiyya commentaries. The writing by al-Shanfarā was subjected to extensive research by national, Western and Arab experts. Through analyzing the most well-known commentaries on Lāmiyyat al-arab, it is possible to evaluate exactly what features call the attention of scholars. In addition, copies of Lāmiyya commentaries stored in manuscript collections deserve an independent careful study and description.

Keywords: codicology, Arabic manuscript, copies, Arabic, pre-Islamic poetry.

The writings of pre-Islamic poets have always aroused persistent interest of researchers. The creative work of al-Shanfara attracted special attention of European experts, despite the fact that lacking information about the poet in Arab sources until the second half of the $8^{\text {th }}$ century often raised the question of authenticity and his works were suspected to represent the later fakes. Their authorship was occasionally attributed to Khalaf al-Ahmar, the Iraqi medieval scholar and a connoisseur of ancient Arab poetry [1, p. 58]. However, their recent in-depth analysis made by I. Yu. Krachkovsky, who referred to Arab sources as well, indicated the presence of extensive specific vocabulary, uncharacteristic of a town man, and therefore confirmed the ancient Arabic origin of qasidas.

No reliable data on al-Shanfara's biography is available; it is believed that he died in the first decade of the $7^{\text {th }}$ century. The poet's nickname Shanfara probably indicates the

(C) Санкт-Петербургский государственный университет, 2019 
exterior feature, i. e., thick lips. According to some sources, his real name was Sabit b. Aus and he belonged to the Azd tribe. Medieval Arabic tradition classifies al-Shanfara as "brigand poet", calling such wanderers by a generic term suluk/sa'alik. Vagabond poets traditionally praised the Bedouin raids, which they took part in [2, p.66].

Since almost nothing is known about the poet's life, his name is associated with many legends. For instance, some Arab sources say that the father of al-Shanfara stole his mother from another tribe and was killed later by the Salaman tribe ${ }^{1}$ that raised the orphaned future poet. It is believed that al-Shanfara was banished from his tribe and spent his life wandering and struggling with many hardships that tempered his character.

According to another version, al-Shanfara was a slave of the Salaman tribe and once fled, vowing to kill a hundred people from this tribe. Over the long years of his wanderings, he took revenge on ninety-nine enemies and was killed in a battle after that. But the legend says that after his own death al-Shanfara killed the hundredth enemy, who died by tripping over the murdered poet's skull [1, p.36, 54].

Ta'abbata Sharran, a vagabond poet and al-Shanfara's comrade-in-arms mourned the death of his friend in verse [1, p. 53].

Particular attention to the pre-Islamic poets emerged in the Middle Ages. For instance, al-Shanfara is mentioned in "The Unique Necklace" by Ibn Abd Rabbihi, the chapter "The Emerald. The Book of Valor", where the author quotes the pre-Islamic poet about death on the battlefield: "Don't bury me. Burying me is forbidden by custom. But be of good cheer, Umm 'Amir. When my head is carried away, - oh hyena, Take the remains of the dust without fail" [3, p. 249]. In The Book of Misers, al-Jahiz quotes al-Shanfara's (without mentioning his name) lines in one of the stories: "If my head is cut off, my best part, Other remains will have be left in the desert". [4, p. 118]. Zakariya al-Qazwini also distinguished al-Shanfara among other poets of the Jahiliyyah period [5, p. 55].

The interest in al-Shanfara's creative work has only increased over time. Thus, Ahmad Faris Shidyaq published a number of monuments of classical Arabic literature, including al-Shanfara's writings with numerous interpretations [6, p. 243].

Al-Shanfara, the "exiled poet", took preference in describing the Bedouin raids. By tradition, his poetry is compared with classical muallaq, where the authors praise tribal patriotism against the main idea - a life in exile [1, p. 36; 7, p. 239]. His most famous qasida Lamiyya includes 68 beyts, consists of several poetic pictures, is written in the tawil meter and reflects the commitment to Bedouin customs traditional for the pre-Islamic works. This work by al-Shanfara is viewed among the best examples of pre-Islamic poetry, as it provides a colorful description of the poet's lonely life in the steppe, Bedouin raids, the author's discontent with the doings of his former fellow tribesmen, and praising the free nomadic life.

The most famous al-Shanfara's writing, Lamiyya got its name for the special repetitive rhyme in the letter "lam". At the same time, the usual three-part writing style is not followed. It is dedicated to one theme, self-praise of a Bedouin lonely hero [8, p. 139]. Among European researchers, this qasida is also known as "The Desert Song”. The work was translated into European languages more than once; Russian translations were made by I. Yu. Krachkovsky, A. A. Dolinina and A. M. Revich. Al-Tantawi showed interest in alShanfara's poetic works, as mentioned by A. E. Krymsky [6, p. 173].

\footnotetext{
${ }^{1}$ In Arabic sources, the tribe is called Salaman, transcribed "Salman" into Russian.
} 
Many Arab scholars addressed this work and commented on it; the most important are commentaries by medieval scholars, al-Zamakhshari and al-Ukbari.

The Institute of Oriental Manuscripts collection contains two Lamiyya copies (B 1496, sheets $28 \mathrm{~b}-32 \mathrm{a}$ and C 780, sheets 76b-77a), as well as a copy of al-Ukbari's work (B 92, sheets $86 a-98 a$ ), which represents a commentary-explanation on the al-Shanfara's qasida.

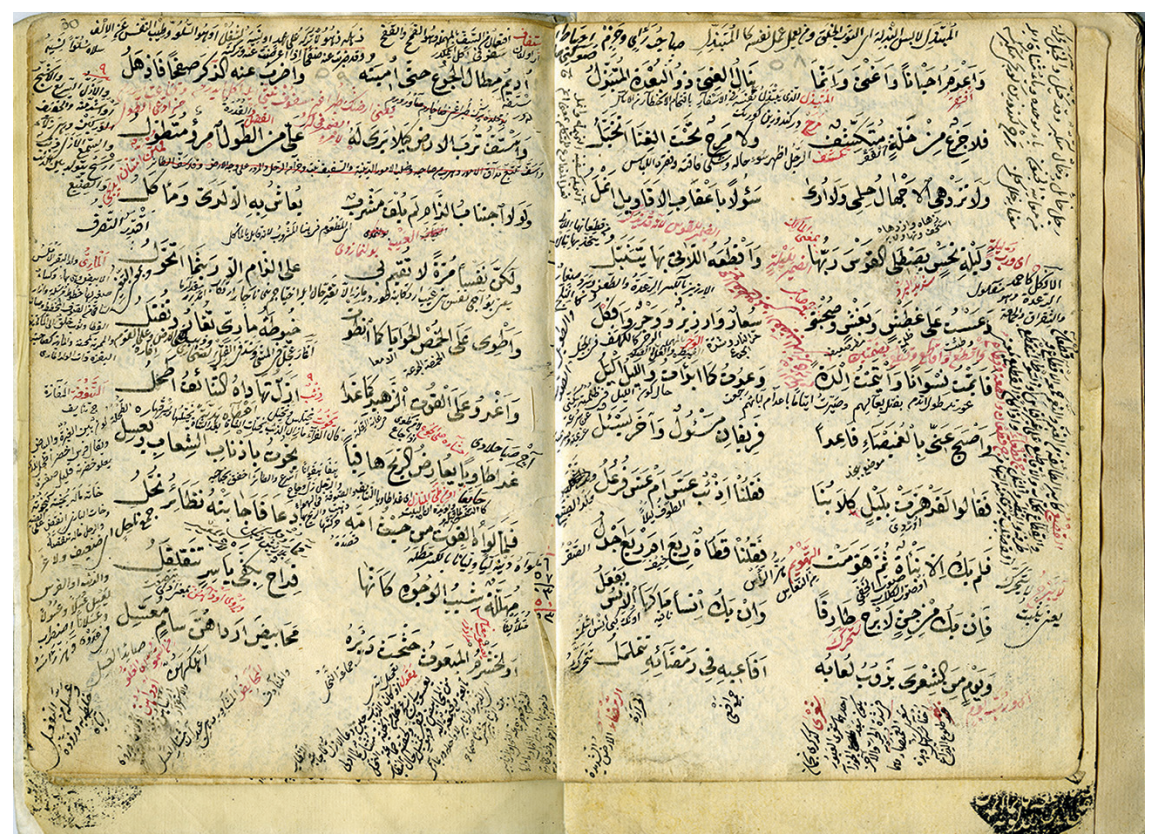

Fig. 1. Manuscript 1496, fragment (sht. 29b-30a)

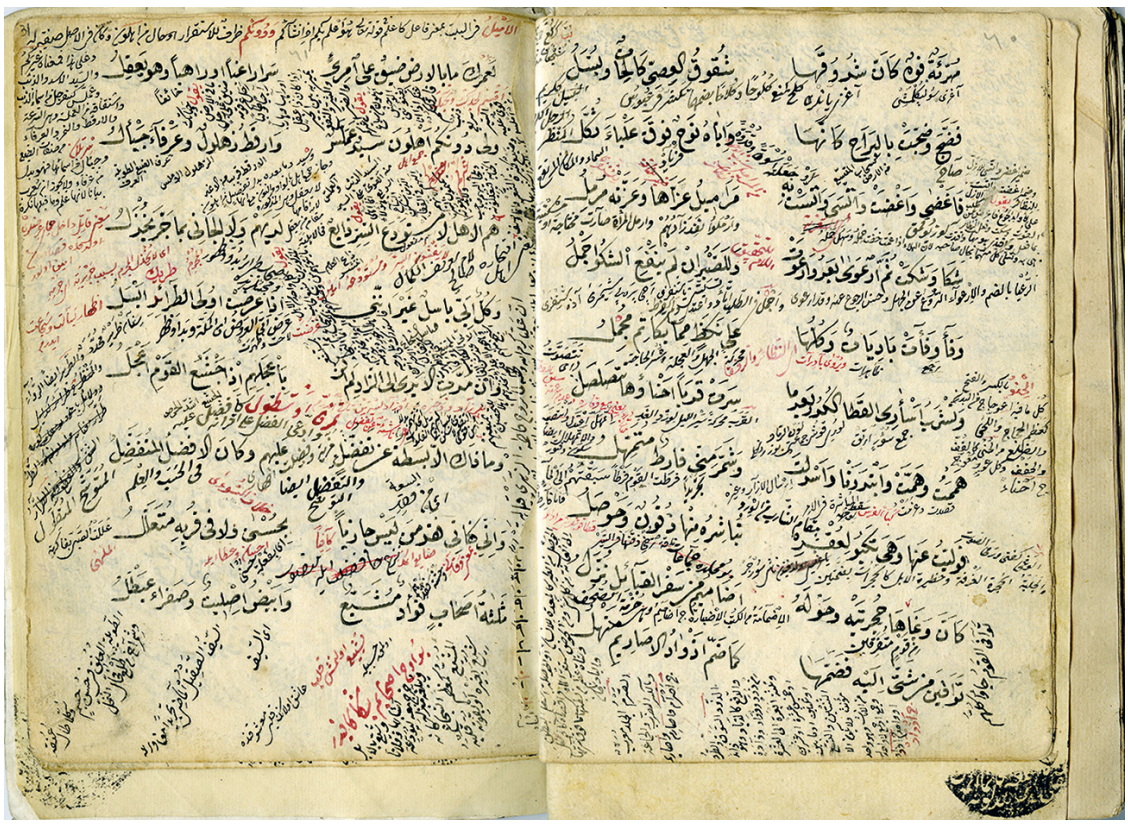

Fig. 2. Manuscript 1496, fragment (sht. 30b-31a) 
Manuscript B 1496 (sheets 28b-32a) represents a convolute of independent copies of eight different qasidas; one of these is Lamiyya by al-Shanfara. Manuscript size: $20.5^{\star} 14 \mathrm{~cm}$; the size of included copies (al-Shanfara and al-Ma'arri) is smaller, $18.5^{\star} 13 \mathrm{~cm}$. Manuscript binding: thin cardboard, glued paper inside. European filigree paper. Handwriting in all copies different, indicative of different calligraphers. Al-Shanfara's copy in naskh handwriting, carry-over words absent. Copy text fully diacritized. Main body in black ink, some commentaries in red ink. Commentaries placed in margins and between lines.

Manuscript sheets 1a, 9b, 27b, 28a, 33b bear owner's seal, inscription as follows:

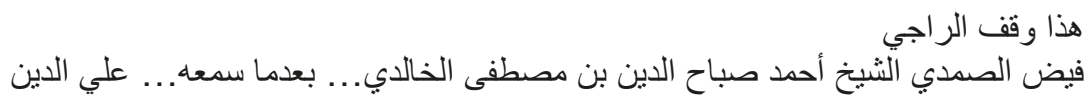

1021

This is the property of Raja Fayd al-Samdi al-Sheikh Ahmad Sabah al-Din b. Mustafa alKhalidi (unlegible) after he heard (unlegible) Ali al-Din 1201.

Copy title with grammatical error, masculine instead of feminine form:

$$
\text { قصيدة لامية للشنفرى وهو عظيم وله شروح كثير }
$$

Lamiyya qasida by al-Shanfara's qasida is great, there are (exist) a lot of commentaries on it.

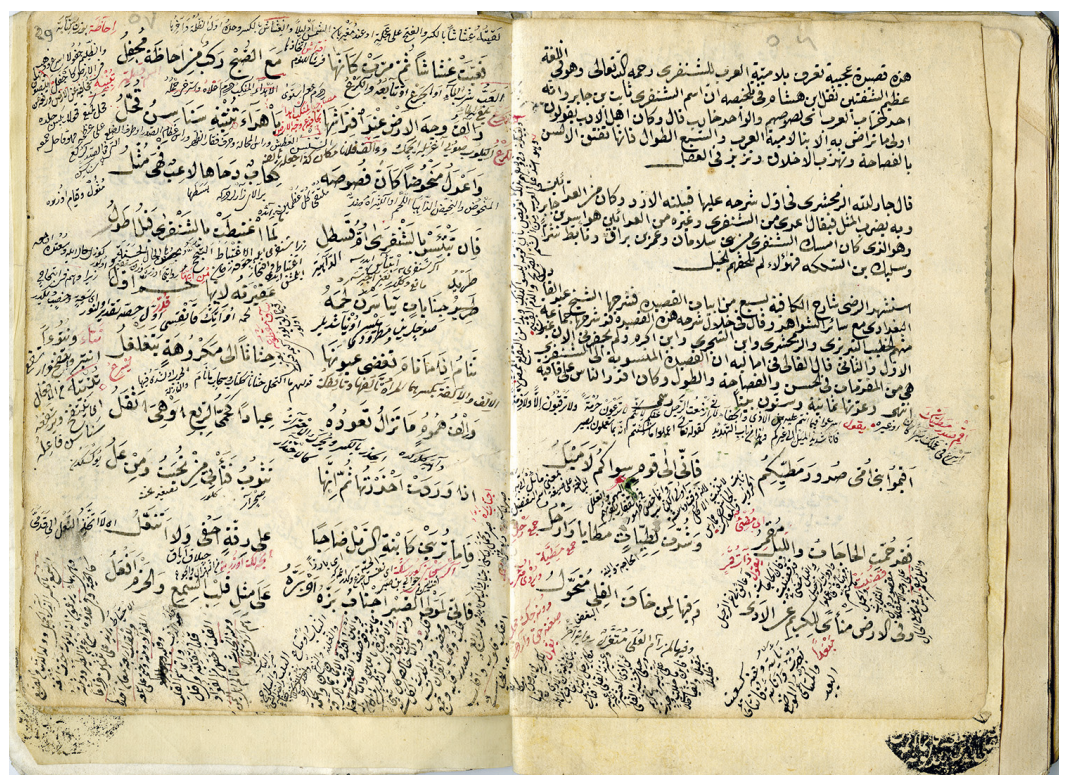

Fig. 3. Manuscript 1496, fragment (sht. 28b-29a)

The text begins with the words:

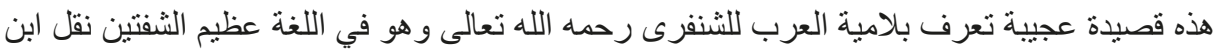

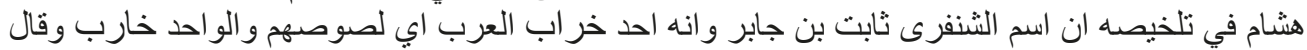


كان اهل الادب يقولون اولى ما تراضى به الابنا لامية العرب والسبع الطوال فانها تفتق الالسن بالفصاحة وتهذب الاخلاق وتزيد في الفضل الاب الفان

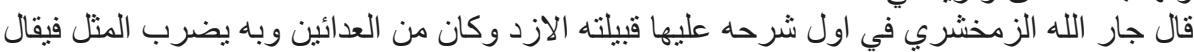
اعدى من الشنفرى و غيره من العدائين الزئ

This amazing verse named Lamiyyat al-Arab belongs to al-Shanfara, may God have mercy on him! Meaning of his name: thick-lipped. b. Hisham wrote in his work that al-Shanfara's name is Sabit b. Jabir and that he is one of the Arab wanderers. Literary scholars said: the first thing that the next (Arab) generations recognized unanimously was Lamiyyat al-Arab and seven muallaqs. They teach eloquence, educate and develop

Then follows a reference to al-Zamakhshari's commentary, who wrote that a proverb about al-Shanfara was created, noting the poet's capability to run fast:

Faster than al-Shanfara.

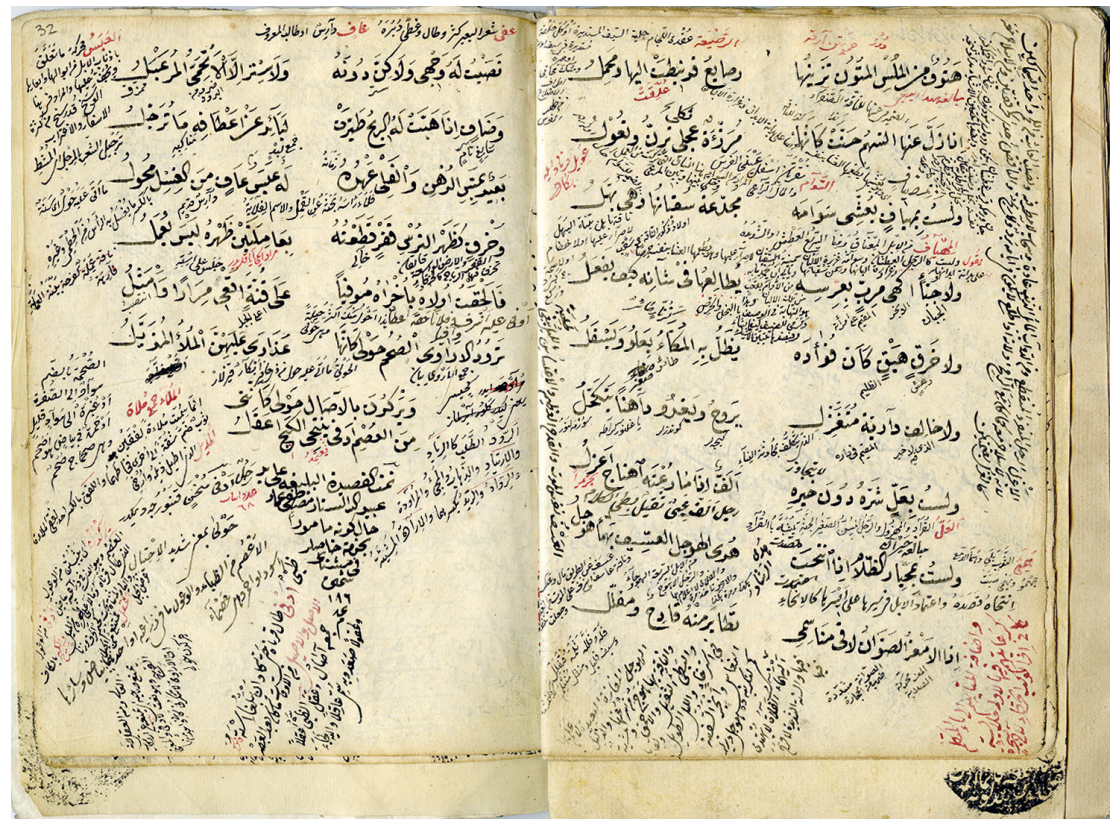

Fig. 4. Manuscript 1496, fragment (sht. 31b-32a)

The colophon text reads as follows:

$$
\text { تمت القصيدة البليخة على يد عبيد الله الستار مصطفى عماد حال كونه مامور ا بخدمة خاصلر في... }
$$

This impressive qasida (copied) by Ubeid Allah al-Sattar Mustafa Imad was completed when he served in a (land allocation institution) in (unlegible) 186.

\footnotetext{
${ }^{2}$ It means 1186 year.
} 


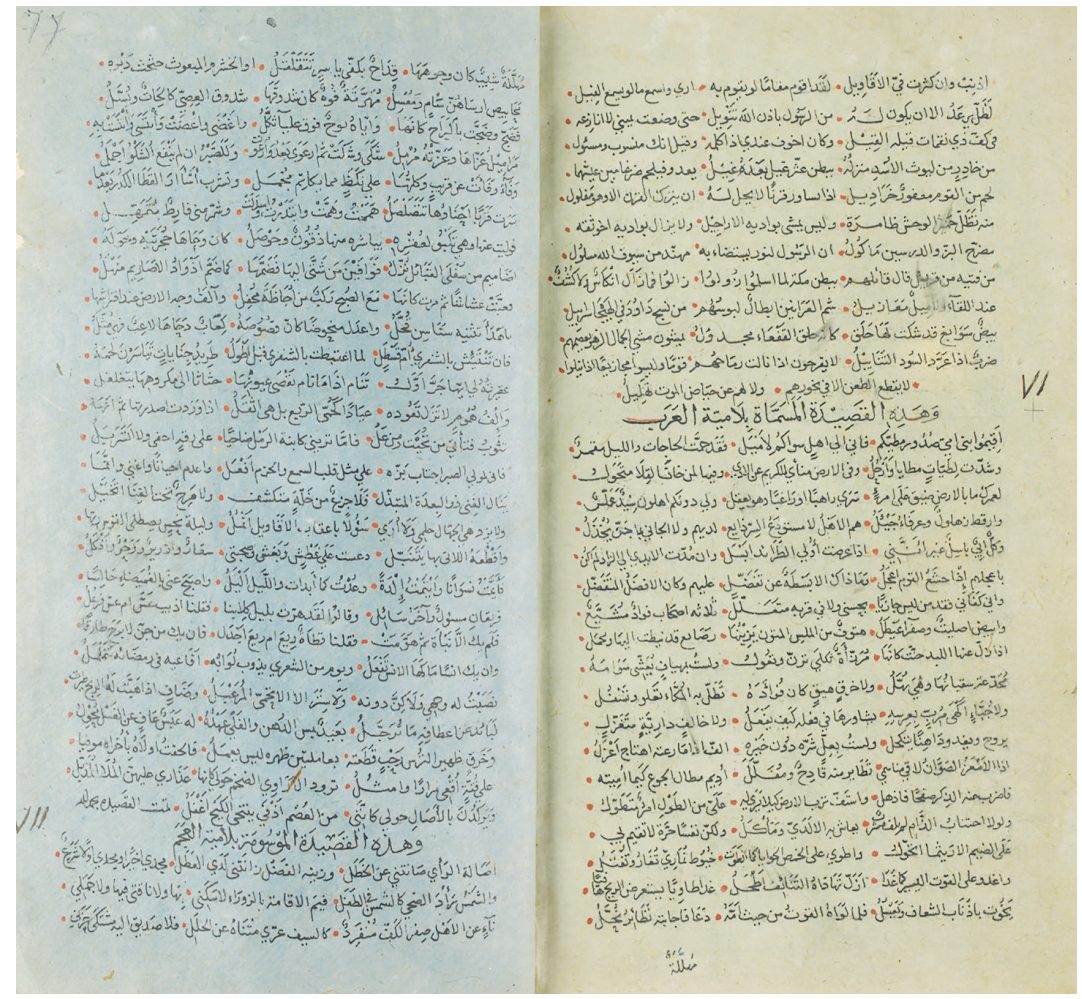

Fig. 5. Manuscript C 780, fragment

The second copy of al-Shanfara's writing is placed in manuscript C 780 (76b-77a), also a convolute. Manuscript size: $22^{\star} 13 \mathrm{~cm}$. Manuscript binding: leather and cardboard. European paper, good condition, different shades: white and blue. All copies made by one hand, in naskh handwriting. Al-Shanfara's copy text fully diacritized; main body in black ink, diacritics in red ink, carry-over words present in all sheets.

The first manuscript page bears owner's seal, inscription as follows:

$$
\text { تملكه العبد الحقبر محمد بن عبد الفتاح جميل الخط }
$$

Belongs to the lamentable slave Muhammad b. Abd al-Fattah - possessor of a beautiful handwriting.

The copy begins with the words:

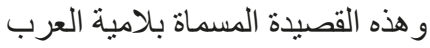

And this is qasida entitled Lamiyyat al-Arab.

Concluding text on sheet 77a not included in traditional colophon:

Qasida is ended, thank God!

تمت القصبية بحمد الله 


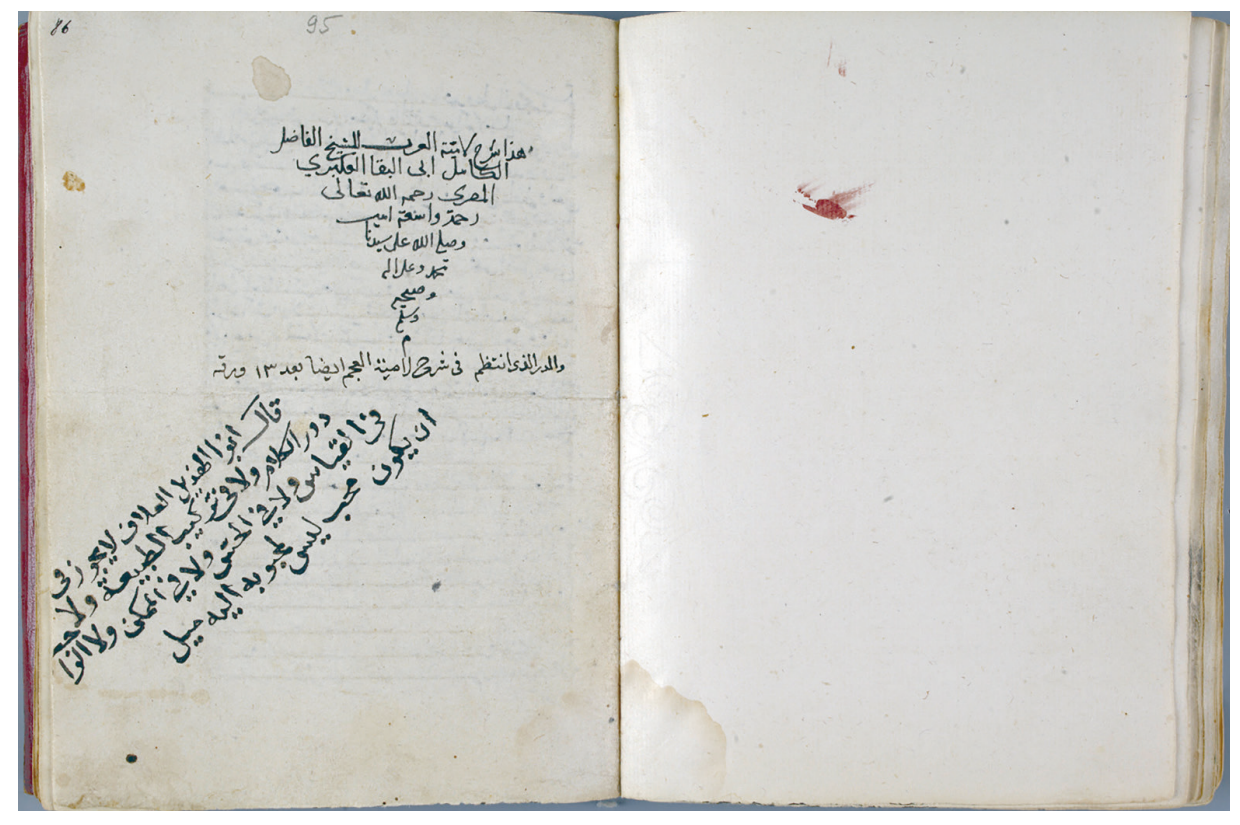

Fig. 6. Manuscript 92 (86 a), fragment

The first examined commentary on al-Shanfara's work belongs to al-Ukbari.

Abd Allah al-Ukbari (1143-1219 / 535-616 Hijri calendar) was born in the ancient city of Ukbara located near Baghdad. As a child, he suffered smallpox and lost sight, but this did not affect his crave for knowledge: al-Ukbari studied grammar, logic, fiqh, hadiths and tafsirs from famous scholars of his time. Al-Ukbari is the author of over thirty works, where commentary on al-Shanfara's writing is of particular interest.

This is a linguistic commentary that presents an analysis of word forms used by alShanfara. Referring to the opinions of famous grammarians, such as Sibawayh and alAhfash, the author gives explanations for difficult words and parses toponyms, by analogy with the linguistic dictionaries principle.

Here, al-Ukbari takes the verses from the Quran as examples and also refers to verses by famous poets. Concise presentation makes the most striking feature of al-Ukbari's commentary. Thus, the text of the commentary is not preceded by the traditional introduction; instead, is starts with the following: Al-Shanfara al-Azdi said ... Al-Ukbari borrowed a lot from al-Zamakhshari's commentary, that's why we see so much in common between these works.

The manuscript B 92 contains the copy of al-Ukbari's work (sheets 86a-98a) and is in convolute with copies of four other works. Manuscript size: $20^{\star} 14.5 \mathrm{~cm}$. Manuscript binding: leather, burgundy ornament. European paper, filigree, solid, smooth, flavescent. Naskh handwriting, carry-over words present. The first copy in the convolute probably made by another calligrapher, also in a neat beautiful naskh. All Lamiyya beyts, لقاق verb and some grammatical features highlighted in red ink.

Copy text contains small number of margin commentaries in black ink.

Calligrapher's name missing. Sheet 01 bears owner's seal, inscription as follows: 


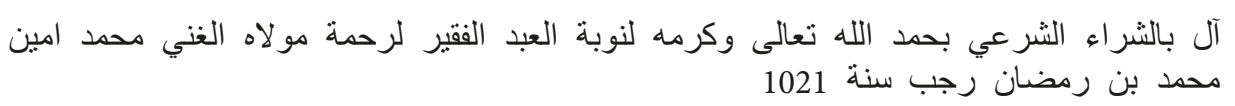

Passed (this manuscript) by legal purchase thanks to God Almighty and his generosity into the hands of a poor slave through the kindness of his wealthy sayyid Muhammad Amin b. Ramadan b. Rajab in 1201.

The same sheet indicates:

$$
\begin{aligned}
& \text { هذا شرح لامية العرب للثيخ الفاضل الكامل أبي البقا العكبري المصري رحمه الله تعالى رحمة واسعة }
\end{aligned}
$$

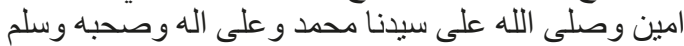

This commentary on (the writing) Lamiyyat al-Arab belongs to the honorable noble Sheikh Abu al-Baqa al-Ukbari al-Misri. May God Almighty be merciful to him with great mercy. Amen. And may God bless and greet our sayyid - Muhammad, his family and his companions.

And further:

$$
\text { والدرر الذي انتظم في شرح لامية العجم أيضـا بعد } 13 \text { ورقة }
$$

And the pearls (works) that were written on the commentary of Lamiyyat al-Ajam also (will be given) 13 sheets after.

This refers to another copy, Lamiyyat al-Ajam, also included in the convolute. Then:

$$
\begin{aligned}
& \text { قال أبو الهذيل العلاف لايجوز في درر الكلام ولا في تركيب الطبيعة ولا حب في } \\
& \text { القياس ولا في الحس ولا في الْمكن ولا ال... أن يكون محب ليس ليس لمحبوبه اليه ميل }
\end{aligned}
$$

Abu Hazil al-Allaf said: It is impossible, neither in the pearls of speech, nor in the structure of nature, nor in love for size, feeling or opportunity or (unlegible) to escape the craving of a lover for a loved one.

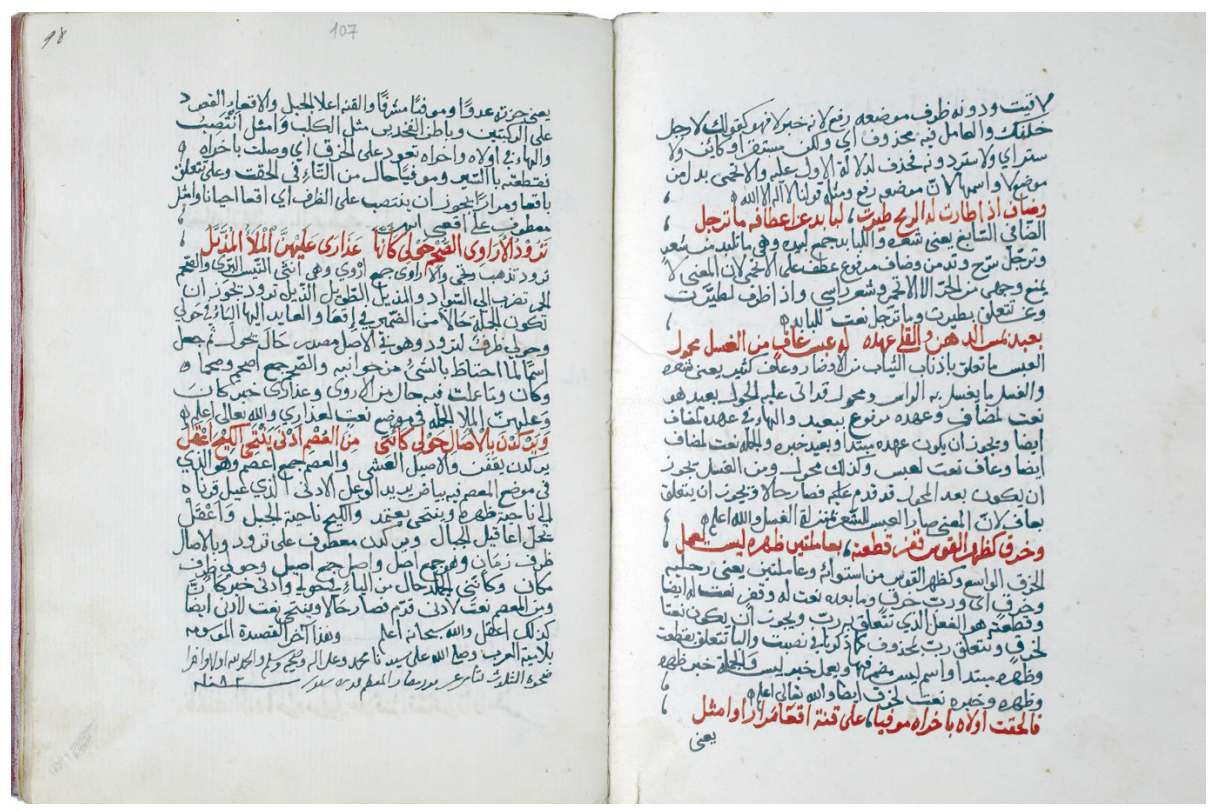

Fig. 7. Manuscript 92, fragment 
Sheet 98:

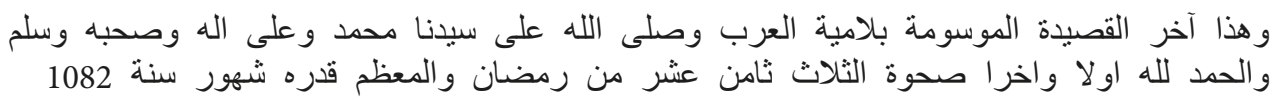

This is the end of qasida called Lamiyyat al-Arab. And may God bless and greet our sayyid Muhammad, his family and his companions. I thank God on the eighteenth day of Ramadan, in the great month, in 1082.

Three copies of Lamiyyath commentaries authored by al-Zamakhshari (780), alMubarrad (781) and al-Turki (739) are stored in the Oriental Department collection, Gorky Research Library, SPbSU.

Abu al-Qasim Mahmoud b. Umar b. Muhammad b. Umar al-Hoarizmi al-Zamakhshari was born in Zamahshar in 1075 (469 Hijri) into a poor family. He attended primary school and also studied under the guidance of his father. Already in his early years, alZamakhshari wrote several philological works. Al-Zamakhshari visited Iraq, Syria, Khorasan, had a large number of students. The scholar died in Khorezm in 1144 (538 Hijri) after returning from Mecca [9, p. 197].

Al-Zamakhshari's commentary on the writing of al-Shanfara is considered the most complete work of this kind. The author carefully analyzes the grammatical and morphological features of the text, taking the famous verses, ayats from the Quran, as well as the most common proverbs as examples. It is noteworthy that al-Zamakhshari used in his interpretations not only the literary Arabic, but also its dialects. The scholar referred to the writings of Sibawayh, al-Ahfash, al-Mubarrad, and others. Moreover, al-Zamakhshari made a phonetic analysis of Lamiyya's text, among other things.

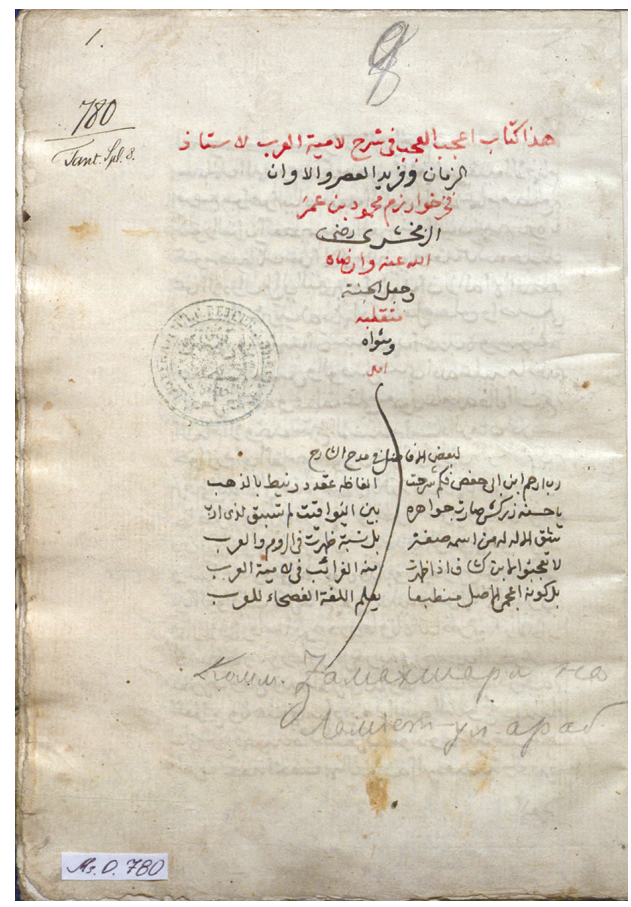

Fig. 8. Manuscript 780, fragment 


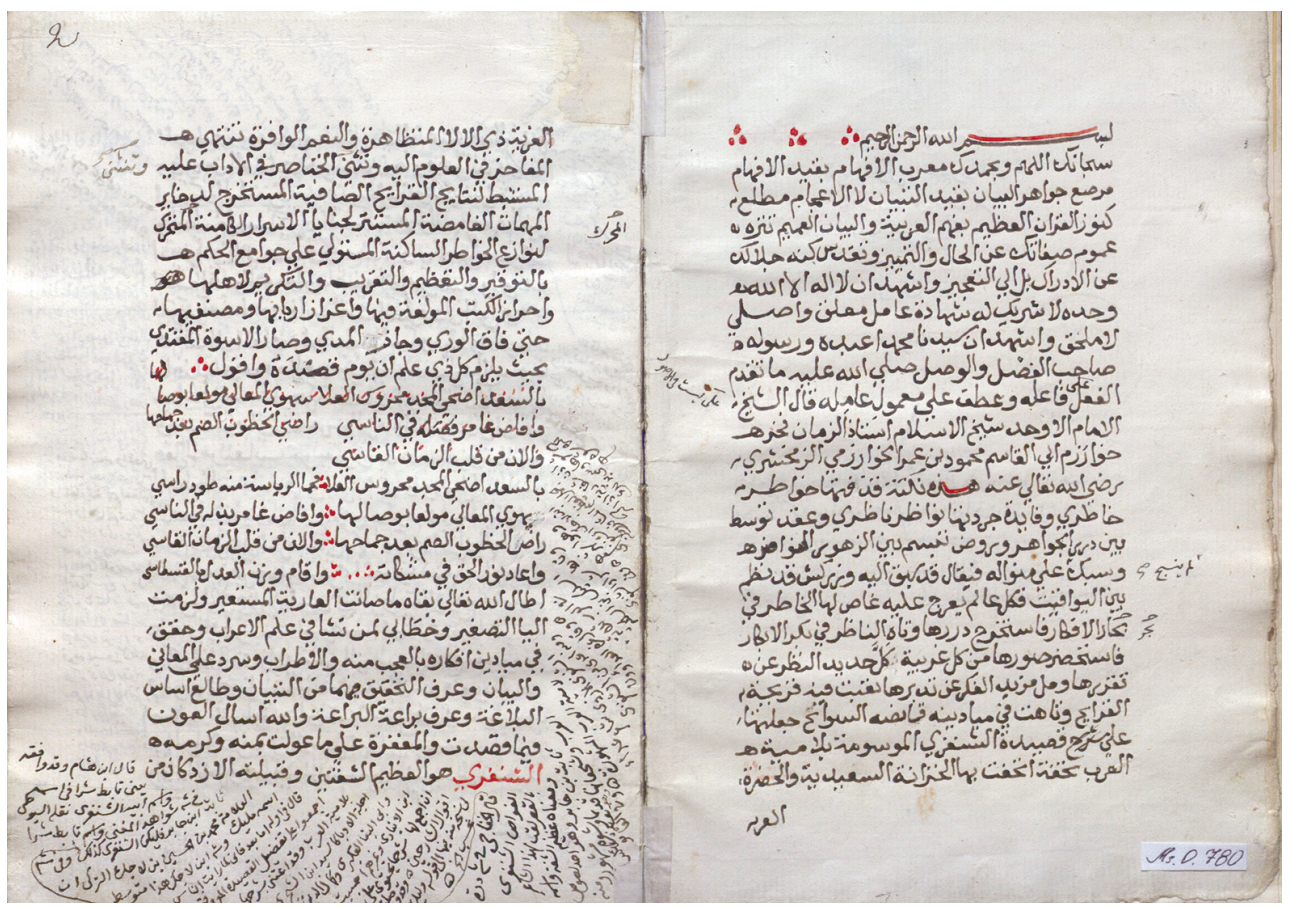

Fig. 9. Manuscript 780, fragment

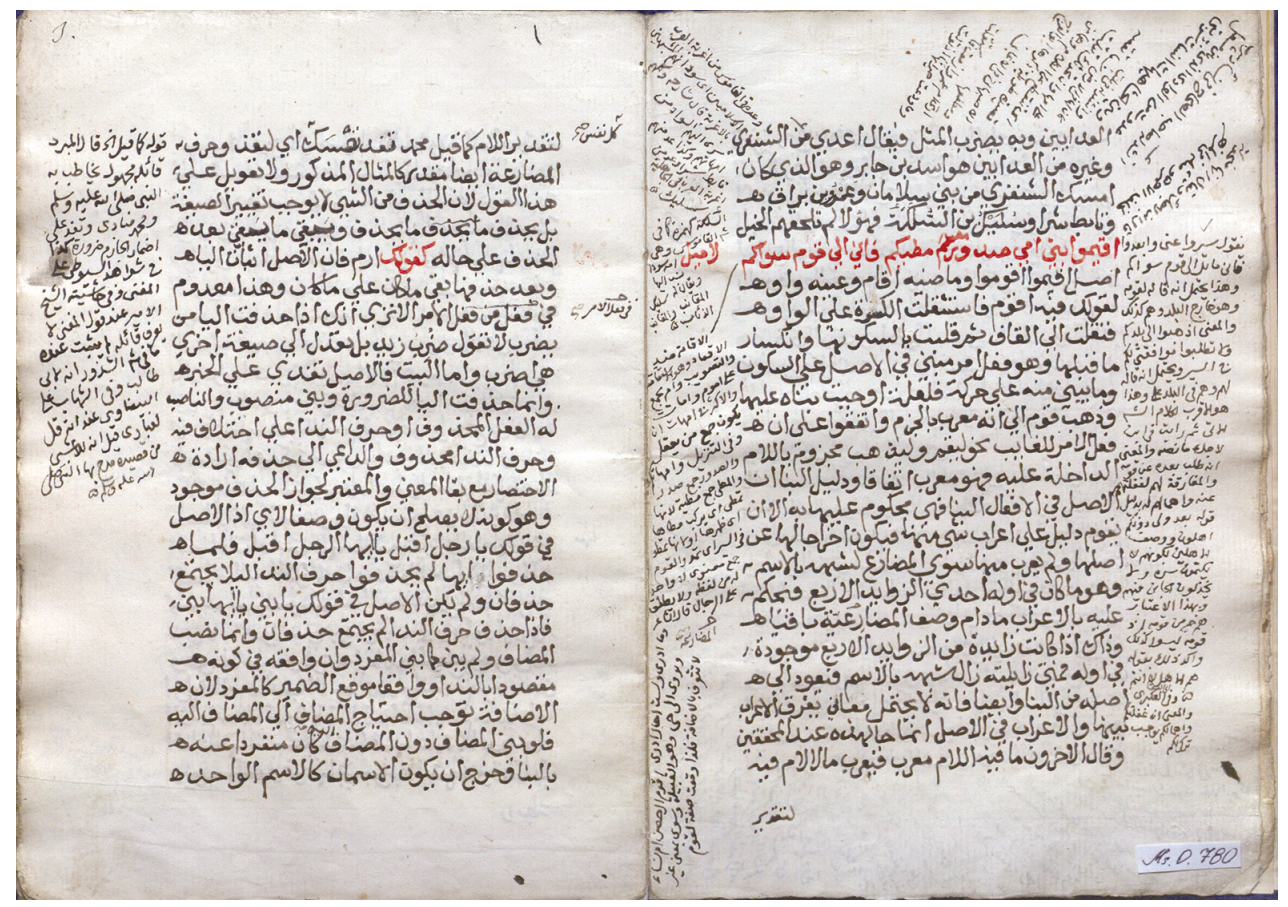

Fig. 10. Manuscript 780, fragment 
The copy of al-Zamakhshari's works is included in Manuscript 780 (44 sht.). Copy title:

$$
\text { اعجب العجب في شرح لامية العرب للزمخشري }
$$

Most surprising in the interpretation of Lamiyyat al-Arab (authored) by al-Zamakhshari.

Manuscript size: $24.5^{\star} 17.5 \mathrm{~cm}$. Binding: fabric-covered cardboard. European paper with filigree. Naskh handwriting, carry-over words present. Main text in black ink; individual words, Lamiyya beyts and al-Shanfara's name highlighted in red ink. Margin commentaries.

Sheet 1, colophon:

$$
\begin{aligned}
& \text { هذا كتاب أعجب العجب في شرح لامية العرب لاستاذ الزمان وفريد العصر و الاوان فخر خوارزم }
\end{aligned}
$$

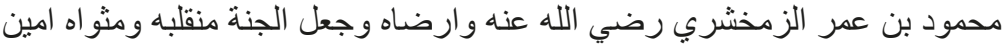

This book is the most amazing (among) commentaries on Lamiyyat al-Arab. It belongs to the only master of his era, the pride of Khorezm, Mahmud b. Omar al-Zamakhshari. May God be pleased with him and grant him a place in Paradise. Amen.

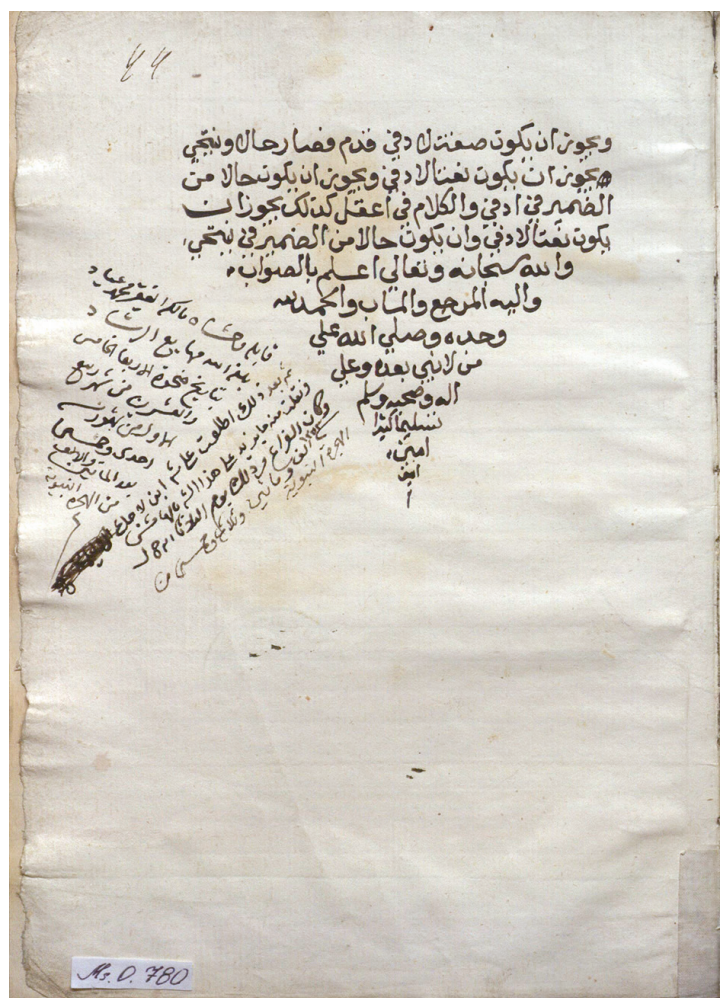

Fig. 11. Manuscript 780, last sheet (sht. 44)

Copying date(s) and calligrapher name not specified.

I. Yu. Krachkovsky notes that despite the fact that the main text was made by other person, commentaries' comparison and extraction were made by al-Tantawi, as evidenced by the respective notes [10, p. 106]. 
Al-Zamakhshari focuses on the grammar and syntax of al-Shanfara's writing, using diverse examples from the Quran.

Al-Mubarrad refers to the most prominent representatives of the Basri school of grammar; he is the author of the famous "al-Kamil' book dedicated to Arabic linguistics. Abu al-Abbas Muhammad b. Yazid b. Abd al-Akbar, or al-Mubarrad, was born in Basra in 826 (210 Hijri) and died in Baghdad in 898 (286 Hijri). He studied with the outstanding scholars of his time, first in Basra and later in Kufa. Most of his activities relate to commenting on Sibawayh's works. Al-Mubarrad was highly esteemed by his contemporaries who called him the most knowledgeable grammarian next to Sibawayh; al-Hamawi noted his excellent knowledge of grammar, eloquence and calligraphic handwriting. A long-lasting dispute between al-Mubarrad and Tallab, his opponent from Kufa, developed into a traditional rivalry between the Basri and Kufi schools of grammar.

Al-Mubarrad focused on the interpretation of words in al-Shanfara's beyts, completely avoiding grammatical and morphological problems. Moreover, the authorship of Lamiyyath commentary, attributed to al-Mubarrad, is questioned by the experts.

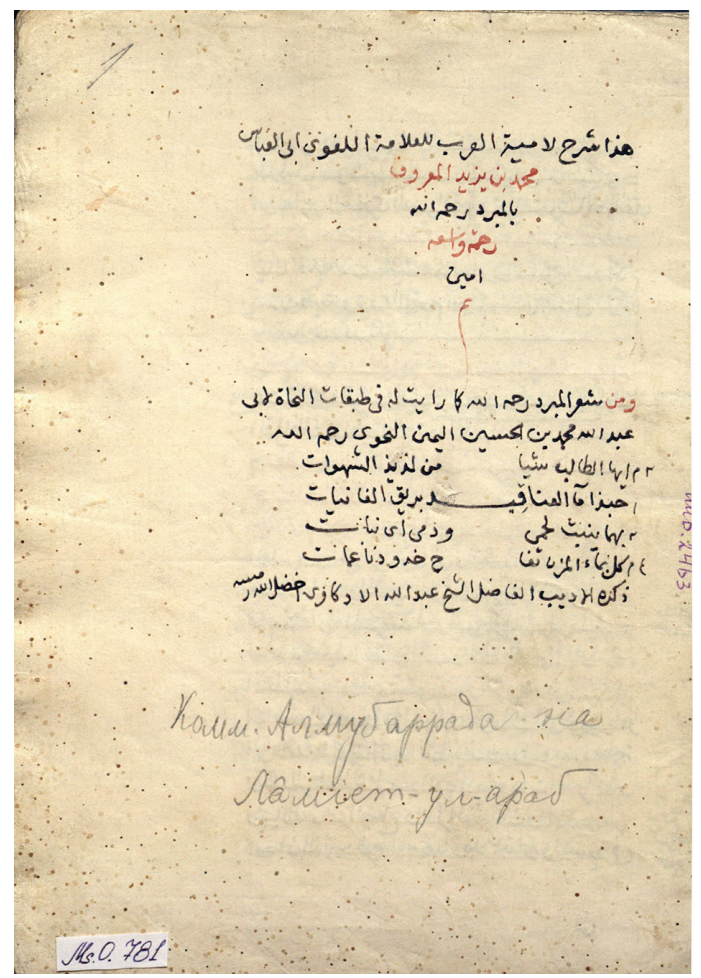

Fig. 12. Manuscript 781, fragment

Al-Mubarrad's copy is contained in Manuscript 781 (sht. 9). Manuscript in good condition, size: $24^{\star} 17.5 \mathrm{~cm}$. Binding: soft cardboard. European paper, with filigree. Text in black ink, Lamiyya beyts highlighted in red ink and numbered. Handwriting mixed, naskh (prevailing) and rukaa (ruq'ah). Carry-over words present. Margin commentaries in black and red ink. 


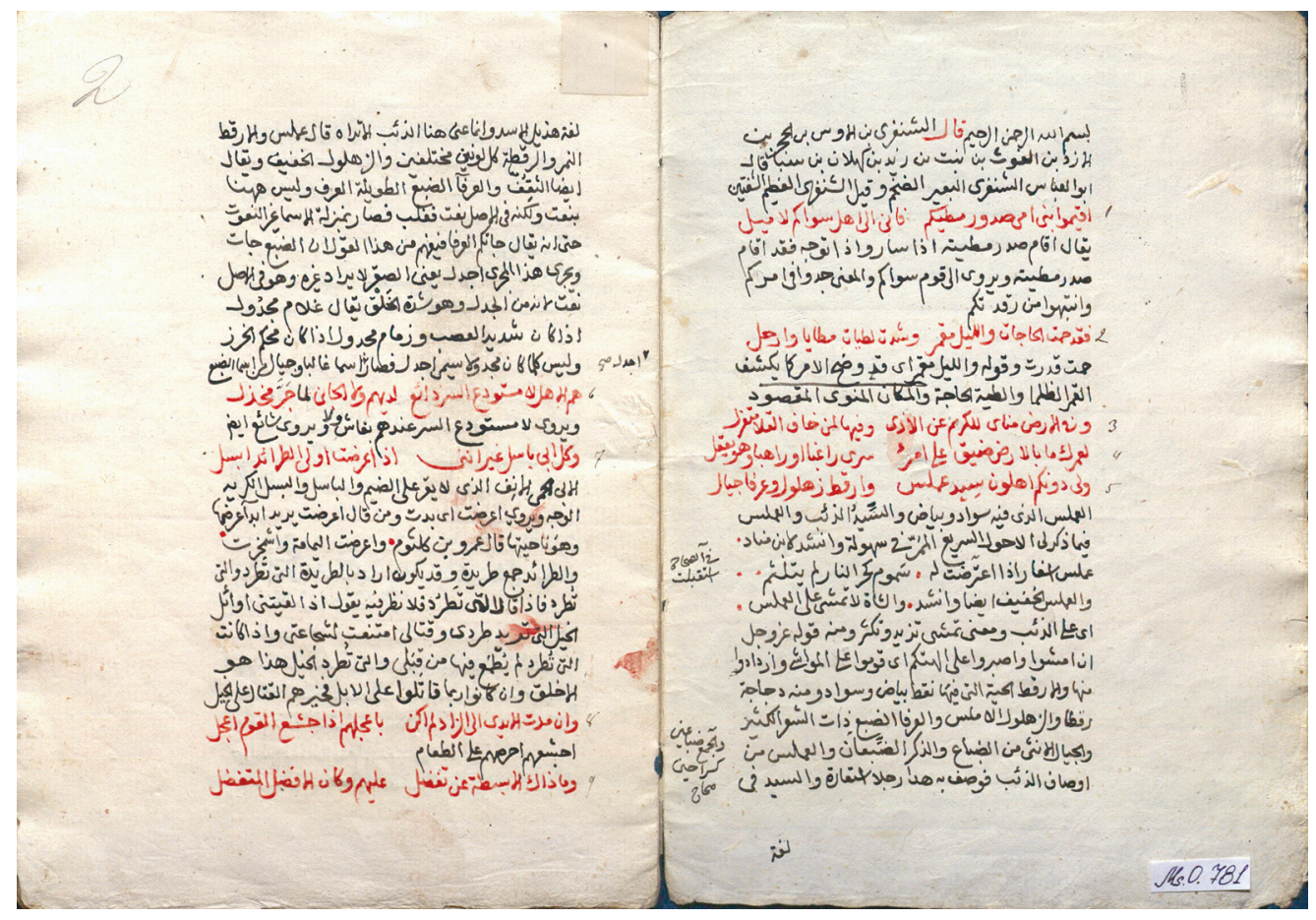

Fig. 13. Manuscript 781, fragment

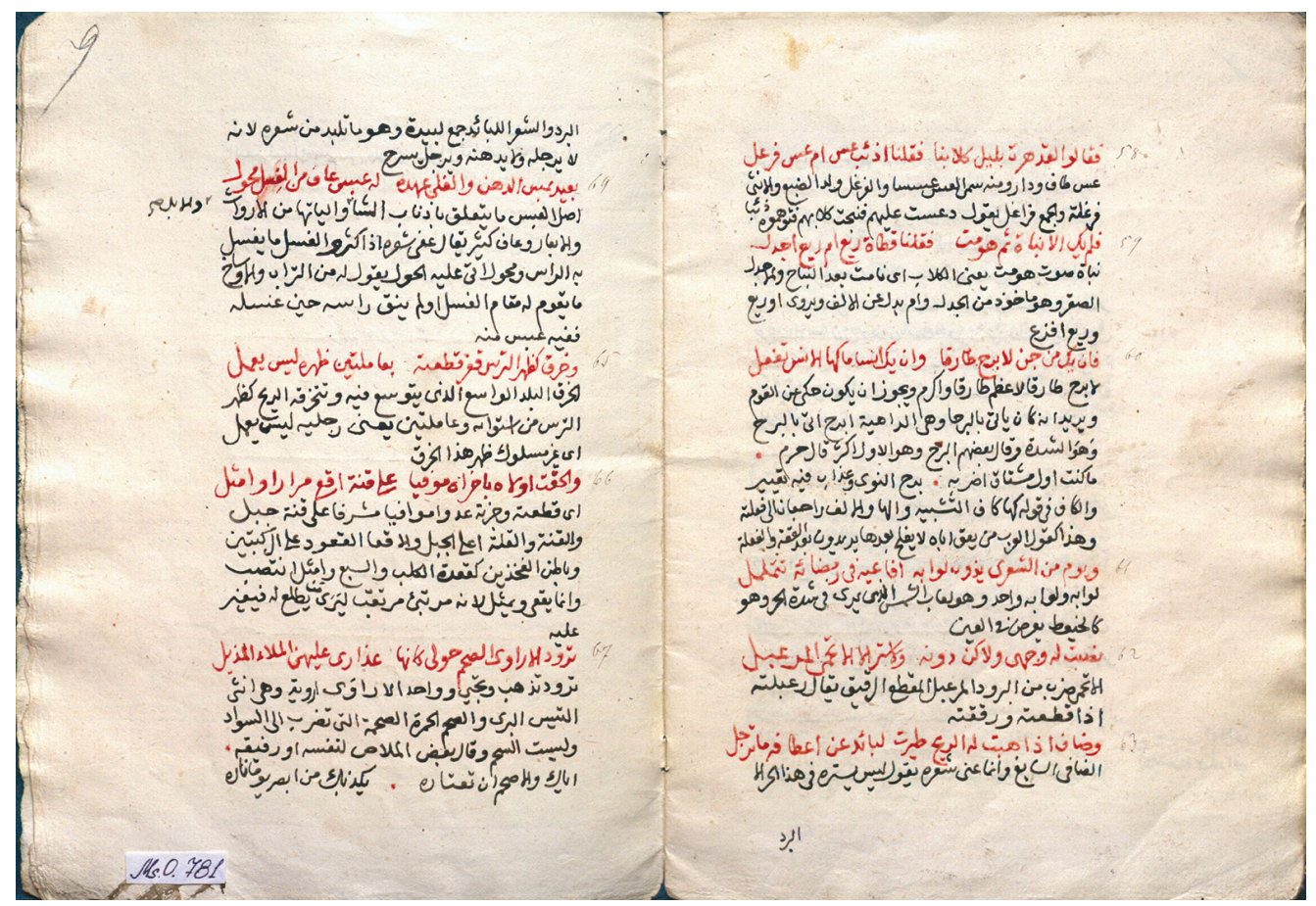

Fig. 14. Manuscript 781, fragment 
Copy title indicated on sht. 1, colophon text as follows:

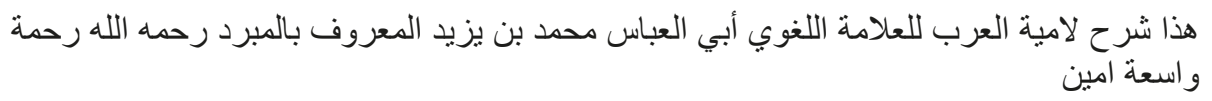

This is a commentary on the Lamiyyat al-Arab by scholar linguist Abu al-Abbas Muhammad b. Yazid, known as al-Mubarrad, may God be merciful to him with great mercy.

Then follows a few poetic beyts authored by al-Mubarrad.

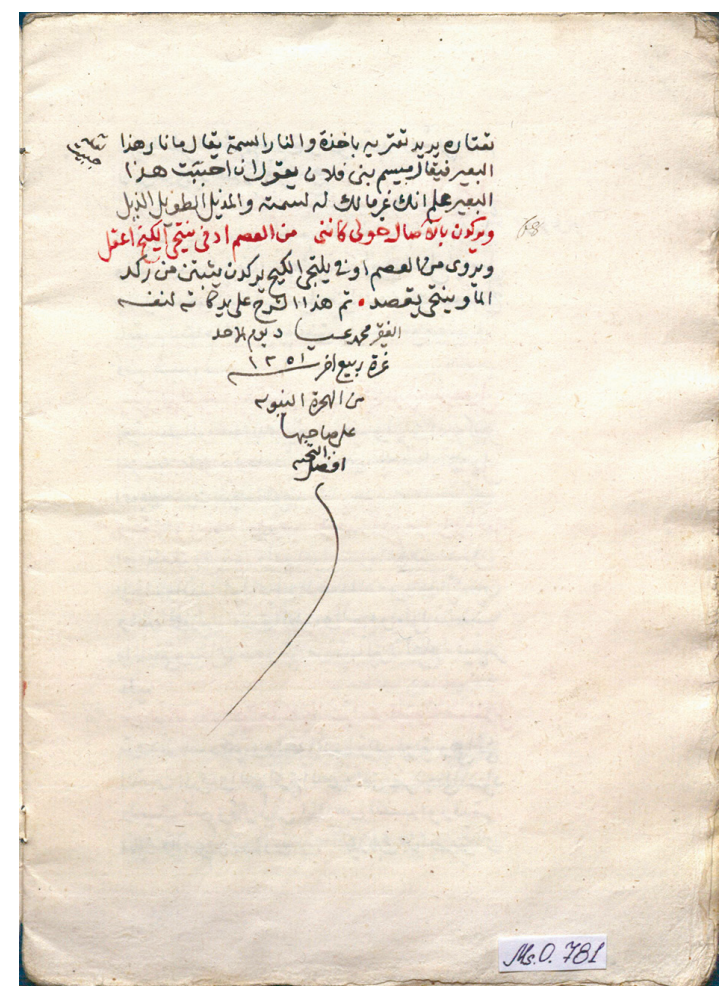

Fig. 15. Manuscript 781, last sheet

Last sheet colophon indicates calligrapher name and end date of copying:

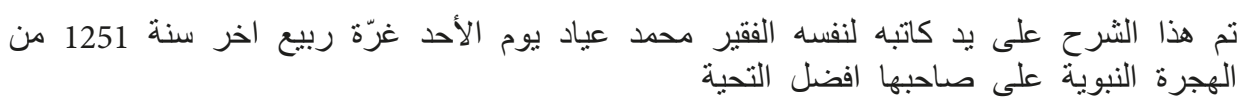

This copy is completed (done) by the hand of the unfortunate Muhammad Ayad (al-Tantawi) on Sunday, at the end of 1251, Hijri.

I. Yu. Krachkovsky notes that "this copy served as the core source for publication of al-Shanfara's poem in The Arabic Reading Book compiled by V.F. Girgas and V. R. Rosen" [10, p. 106].

The third manuscript copy $(739,28$ sht.) containing Lamiyya commentary by $\mathrm{Mu}-$ hammad b. al-Hussein b. Lajik al-Turki ${ }^{3}$ is also stored in the SPbSU library collection.

\footnotetext{
${ }^{3}$ No data on al-Turki were found.
} 


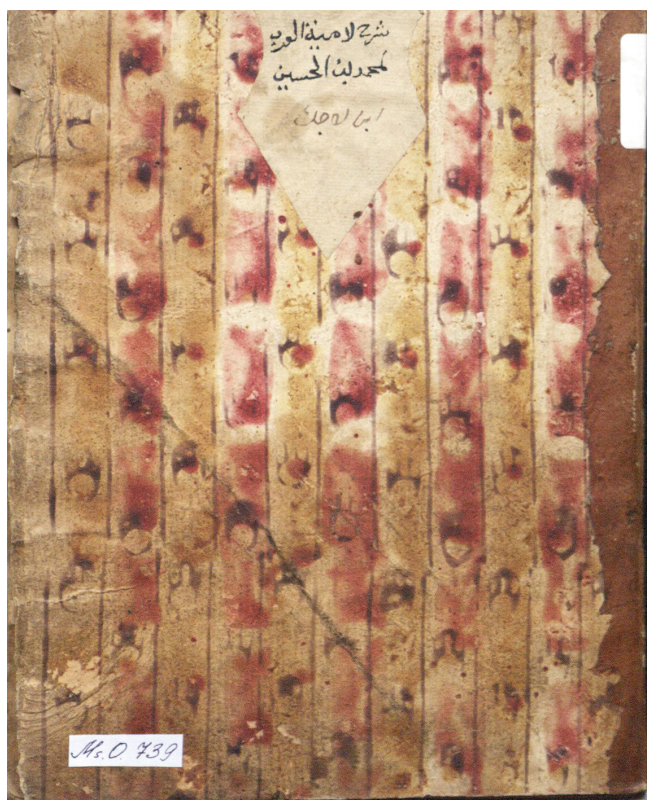

Fig. 16. Manuscript 739, binding

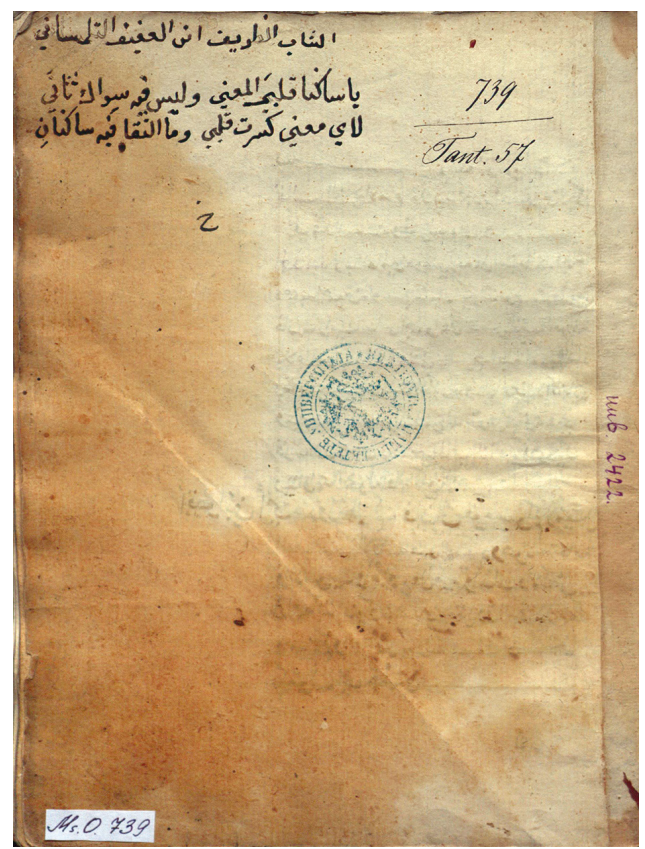

Fig. 17. Manuscript 739, fragment

The most notable features of Lamiyya commentary by al-Turki, is that maximum attention is paid to the interpretation of difficult words: al-Gharib (Difficult words) section provides descriptions of birds, animals, etc., whose names are found in al-Shanfara's writing; the meaning of each beyt is explained in al-Mana (Meaning) section. Unlike other commentators, al-Turki refers to scholars' works only rarely and gives almost no example 
citations from famous poems. The author provides some grammar notes, antonyms, but only occasionally.

Manuscript size of: $22.5^{\star} 16.5 \mathrm{~cm}$. Thin leather binding. European filigree paper, flavescent. Main text in black ink, some words in red ink. Naskh handwriting, carry-over words present. Copy text diacritized. Main body in black ink, some commentaries in red ink. Commentaries placed in margins.

Sheet 1 shows two poetic beyts by Shams al-Din Muhammad b. Afif al-Din Suleiman b. Ali al-Tilimsani, a famous wit of that time ${ }^{4}$ :

Oh you living in my tired heart

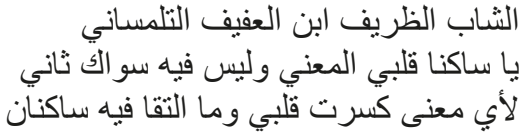

There is no one but you in it (heart)

Why did you break my heart?

Two did not meet in it.

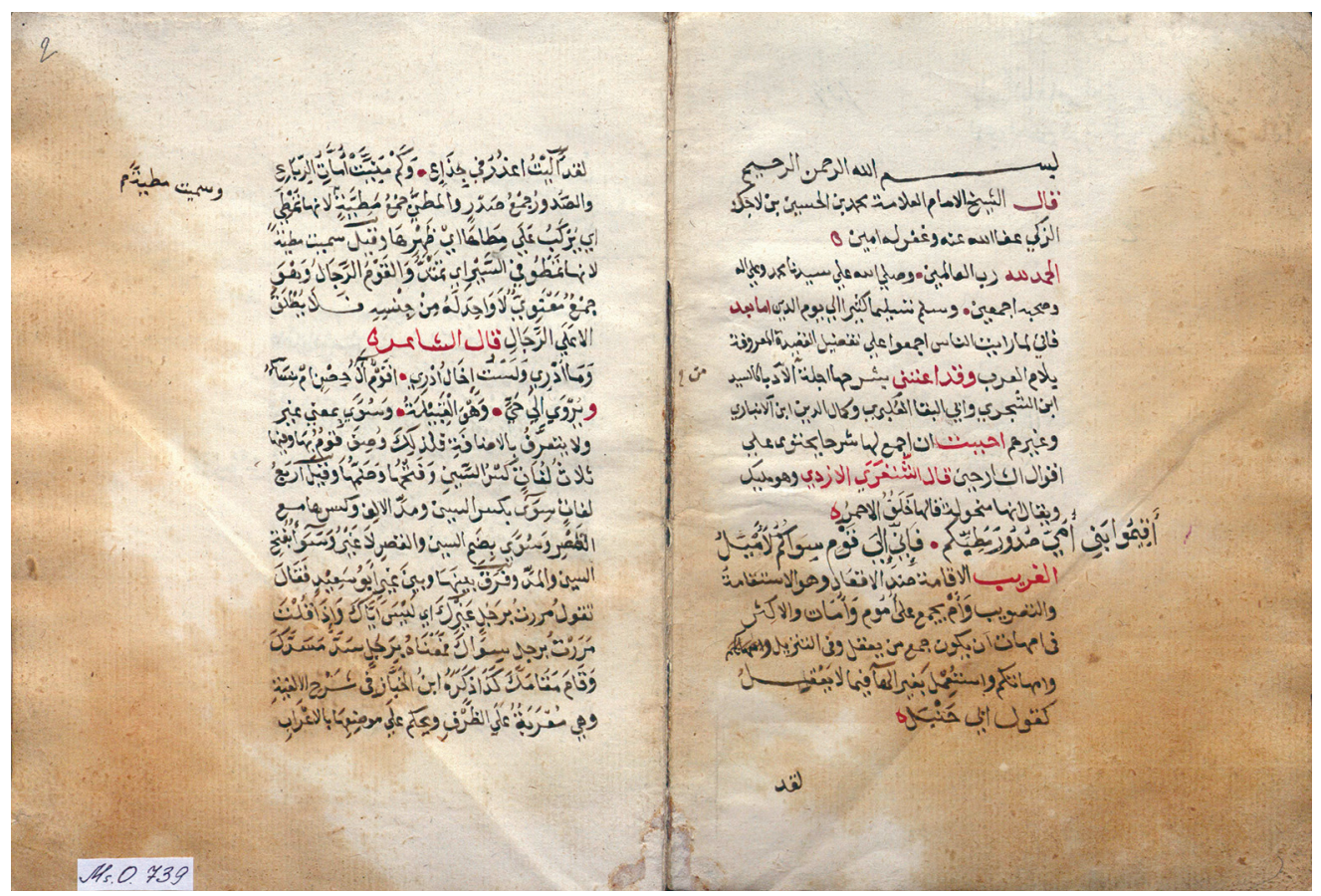

Fig. 18. Manuscript 739, fragment

Sheet $1 \mathrm{~b}$ begins with the traditional basmala:

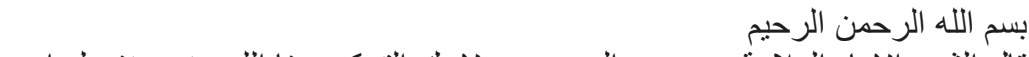

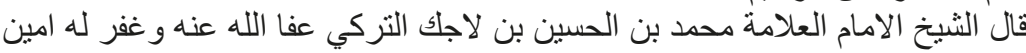

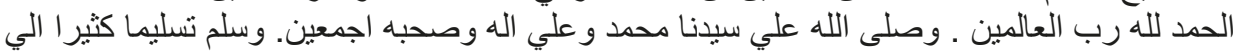
يوم الدين اما بعد فاني لما رايت الناس اجمعوا علي تفضيل القصيدة المعروفة بلام العرب وقد اعتنى بشرحها

${ }^{4}$ Al-Tilimsani was a Cairo-born poet, lived and died in Damascus (1263-1289). His father was also a poet from Tilimsan city in Algeria. 


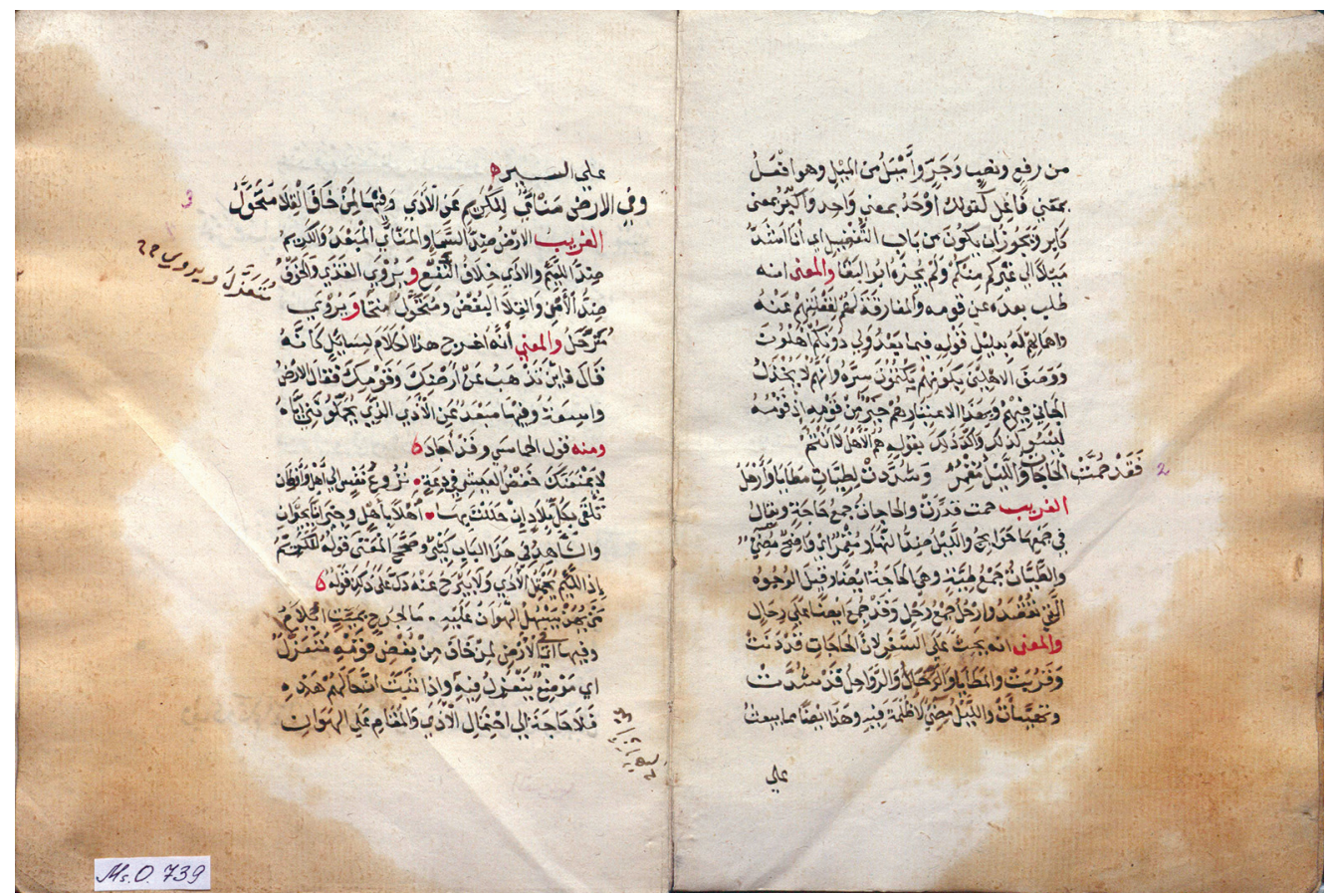

Fig. 19. Manuscript 739, fragment (sht. 1-1b)

اجلة الآدبا كالسيد ابن الثجري وابي البقا العُكبري وكمال الدين ابن آلانباري و غير هم احبيت ان اجمع لها شرحا

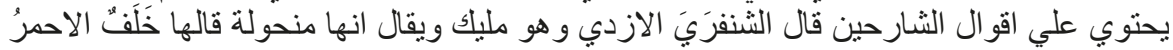

In the name of God most gracious and most merciful,

Sheikh Imam said, scholarly man Muhammad b. al-Hussein b. Lajik al-Turki, may God forgive him and have mercy. Amen.

Thank God, Lord of the worlds. And may God bless and greet our sayyid - Muhammad, his family and his companions. And may he stay blessed until Judgment Day.

After I saw that all people appreciated the famous Lam al-arab ${ }^{5}$ qasida and the greatest literary scholars, such as Ibn al-Shajari, Abu al-Baqa al-Ukbari, Kamal al-Din b. al-Anbari and others, commented on it, I wanted to collect a commentary that contains the words of interpreters. (Lamiyya) Created by al-Shanfara al-Azdi, he is its author. But they say that it (Lamiyya) is a fake and was created by Halaf al-Ahmar.

Sheet 28, colophon:

$$
\text { وقد تم ذللك الثرح بحمد الله وعونه وحسن توفيقه بالتمام و الكمال }
$$

Ended.

This commentary is completed successfully thanks to God and His help.

Information on calligrapher name and copying date absent.

The writing by al-Shanfara was subjected to extensive research by national, Western and Arab experts. Through analyzing the most well-known commentaries on Lamiyyat

5 This refers to Lamiyyat al-Arab. 


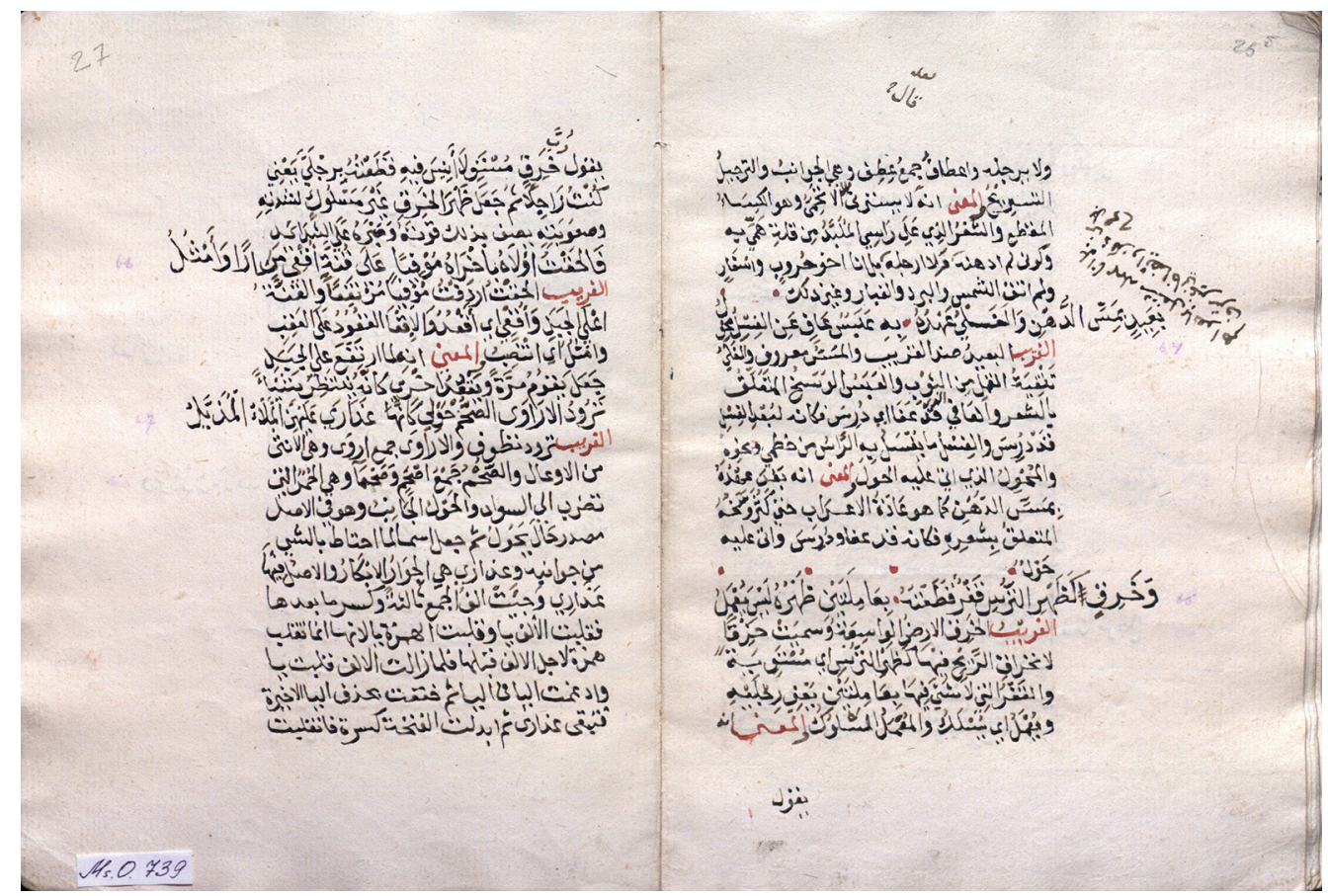

Fig. 20. Manuscript 739, fragment

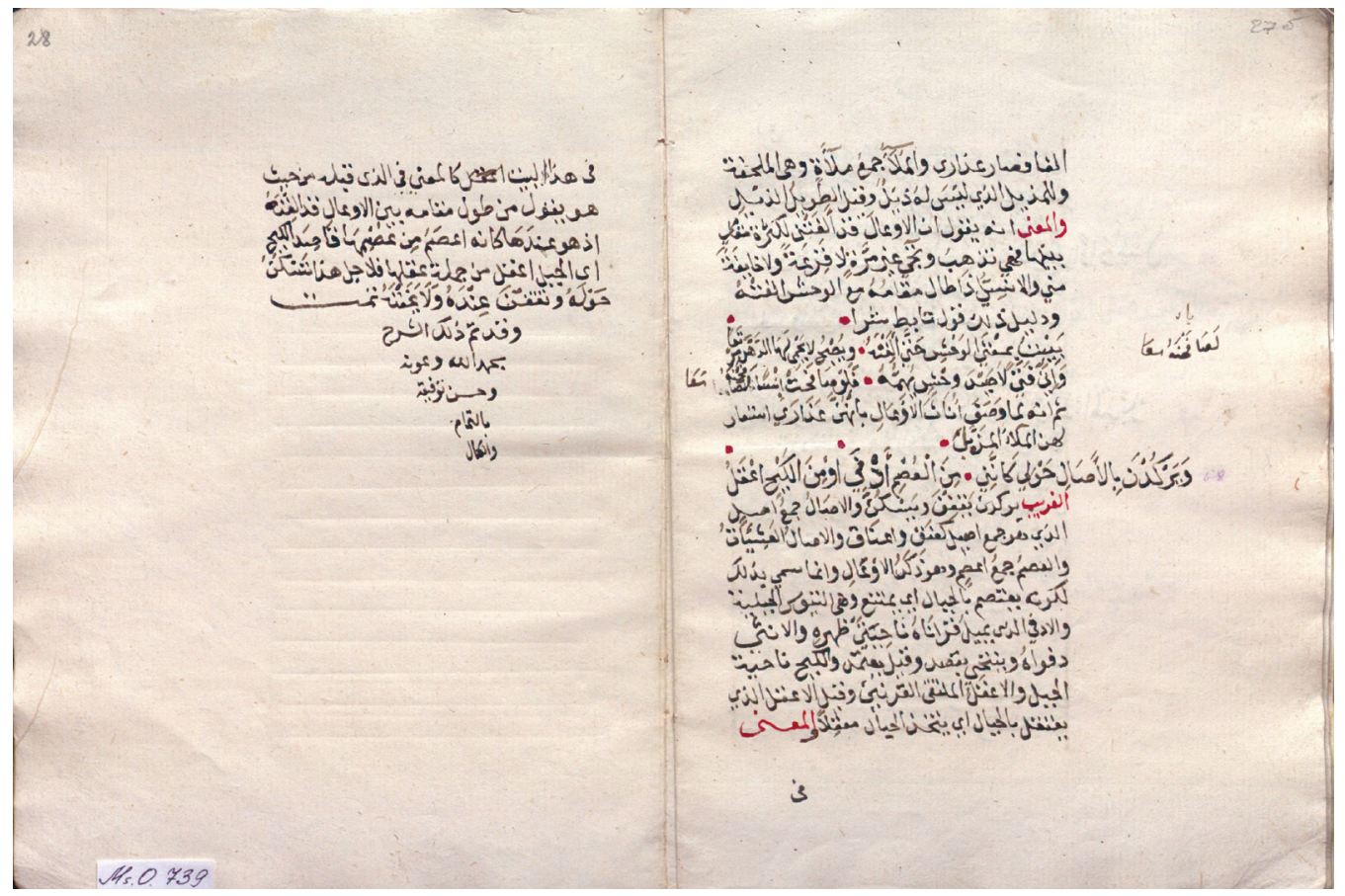

Fig. 21. Manuscript 739, last sheet 
$a l$-arab, we can evaluate exactly what features are the most intriguing and call the attention of scholars. In addition, copies of Lamiyya commentaries stored in manuscript collections deserve an independent careful study and description.

\title{
References
}

1. Abd al-Halim Hanafi. Lamiyyat al-arab li-Shanfara. Sharh wa dirasa. Cairo, 2008. (In Arabic)

2. Filshtinskiy I. M. History of Arabic Literature from the $5^{\text {th }}$ to the beginning of the $10^{\text {th }}$ century. Moscow, 1983. 524 p. (In Russian)

3. Ibn Abd Rabbihi. The marvelous necklace. Transl., introd. and comment by B.Y. Shifdar. Poetry transl. by V. Igelnitskaya. Moscow, 1985. 477 p. (In Russian)

4. Al-Jahiz. The Book of the Greedy ones. Transl., introd. and comment by H.K. Baranov. Poetry transl. by A. Revich. Moscow, 1985. 477 p. (In Russian)

5. Demidchik V.P. World of wonders in the Arabic Literature in $13^{\text {th }}-14^{\text {th }}$ centuries. Moscow, 2004. $277 \mathrm{p}$. (In Russian)

6. Krymsky A. E. History of Modern Arabina Literature (11 $1^{\text {th }}-20^{\text {th }}$ centuries). Moscow, 1971. 794 p. (In Russian)

7. Krachkovsky I. Y. Ash-Shanfara. The Desert Song. Selected works. Vol. 2. Moscow - Leningrad, 1956, pp. 238-245. (In Russian)

8. Arabian Olden Time. From Ancient Arabian Poetry and Prose. Transl. by L. A. Dolinina. Polosin. Moscow, 1983. 142 p. (In Russian)

9. Hana Yafia Yousif Jamil, E. K. Akhmatshina. Copies of the manuscript Atwāq Al-dahab al-Zamahsharī from the Collections of the Institute of Oriental manuscripts of the Russian Academy of Sciences and the Oriental Department of Gorky Research Library of St. Petersburg State University. Vestnik of Saint Petersburg University. Asian and African Atudies, 2017, vol. 9, no. 2, pp. 196-210.

10. Krachkovsky I. Y. Sheikh Tantavi the Professor of SP University. Leningrad, 1929. (In Russian)

Received: July 10, 2019

Accepted: September 26, 2019

Authors'information:

Yafia Yousif Jamil Hana — PhD in Philology, Associate Professor; yhana@mail.ru

Amalia A.Mokrushina — PhD in Philology, Associate Professor; kodzik@inbox.ru

\section{Списки сочинения аш-Шанфары Лямийа и списки комментариев к нему в фонде Института восточных рукописей и в собрании Восточного отдела библиотеки им. Горького}

\author{
Яфиа Юсиф Джамиль Хана, А. А. Мокрушина \\ Санкт-Петербургский государственный университет, \\ Российская Федерация, 199034, Санкт-Петербург, Университетская наб., 7-9
}

Для цитирования: Hana Yafia Yousif Jamil, Mokrushina A. A. Lamiyya by al-Shanfara and its Commentaries: Copies Available in the Holdings of the Institute of Oriental Manuscripts and the Oriental Department Collection, Gorky Research Library // Вестник Санкт-Петербургского университета. Востоковедение и африканистика. 2019. Т. 11. Вып. 4. С. 493-512. https://doi.org/10.21638/spbu13.2019.406

Статья посвящена ставшему в последнее время актуальным вопросу изучения и описания восточных рукописей. В настоящем исследовании собраны факты из жизни известного доисламского поэта аш-Шанфары, рассматриваются особенности его самого 
известного произведения - Лямийа. Основное внимание уделяется спискам этого сочинения, а также спискам комментариев на него, хранящимся в фонде Института восточных рукописей и в собрании Восточного отдела библиотеки им. Горького СПбГУ. Поэзия Аш-Шанфары традиционно противопоставляется произведениям авторов классических муаллак, воспевающих родовой патриотизм, из-за основной идеи жизни в изгнании. Лямийа приобрела свое название благодаря особой повторяющейся рифме. Среди европейских исследователей получило распространение и другое название касыды - «Песня пустыни». Авторы проводят анализ особенностей различных списков сочинения аш-Шанфары, а также рассматривают наиболее важные моменты различных комментариев на его произведение. В статье приводятся иллюстрации некоторых листов списков сочинения аш-Шанфары и списков комментариев на Лямийю. Несмотря на то что сочинение аш-Шанфары уже неоднократно подвергалось исследованию отечественных, западных и арабских специалистов, анализ наиболее известных комментариев на Лямийат ал-араб позволяет оценить, какие именно особенности привлекали внимание ученых. Кроме того, хранящиеся в рукописных фондах списки сочинений-комментариев на известное произведение аш-Шанфары, сами по себе заслуживают тщательного изучения и описания.

Ключевые слова: кодикология, арабская рукопись, списки сочинения, арабский язык, доисламская поэзия.

Статья поступила в редакцию 10 июля 2019 г., рекомендована к печати 26 сентября 2019 г.

Контактная информация:

Хана Яфиа Юсиф Джамиль - канд. филол. наук, доц.; yhana@mail.ru, Мокрушина Амалия Анатольевна - канд. филол. наук; kodzik@inbox.ru 